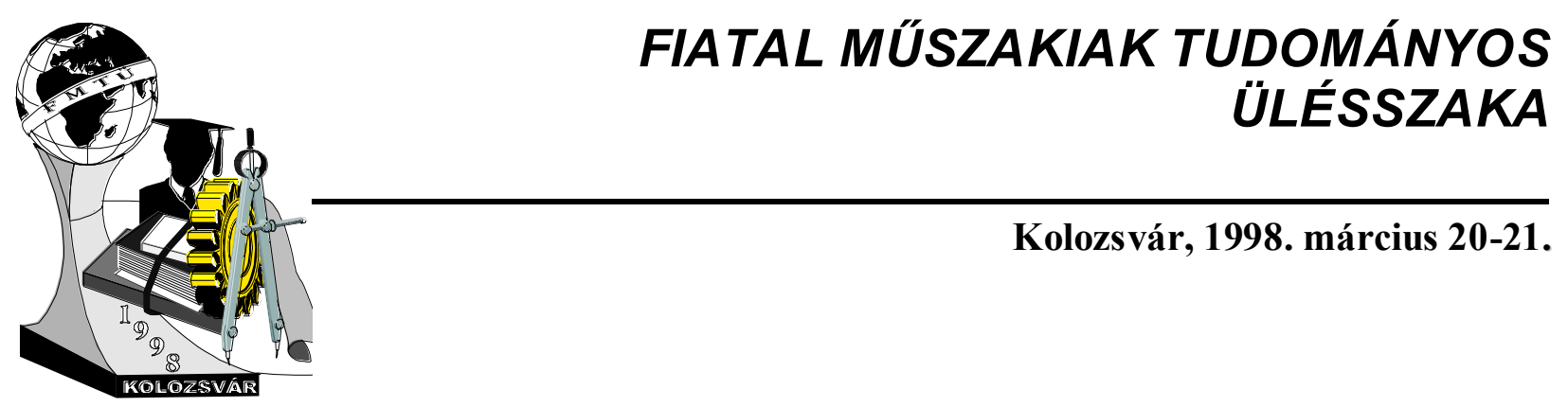

\title{
Diagnosztikai módszerek
}

\author{
Rácz József
}

\begin{abstract}
In this article we would like to show in the different methods of vibration diagnostics. The basis of the classification can be different things so we were forced to choose from these respects.

The chosen respects are the follows:

- time of measuring

- frequency band

- parameter is to be measured

- way of analyzis

\section{Bevezetés}

Napjaink legföbb követelménye, hogy a termelés, szolgáltatás nem állhat meg, ami a gépek folyamatos müködését vonja maga után. Ez egyrészt azt is jelenti, hogy a szükséges vizsgálatokat, méréseket, ellenőrzéseket müködés közben, a gép leállítása nélkül kell elvégezni, de azt is, hogy olyan állapotellenőrző rendszerre van szükség, amely megbízhatóan és jó előre jelzi a meghibásodásokat. Ezen feltételek teljesítése céljából alkalmazzák a különböző diagnosztikai módszereket.

A diagnosztikai módszereket szerteágazóságuk miatt sokféle szempont szerint lehet csoportosítani. Ezek közül talán a legelterjedtebb módszer a rezgésdiagnosztika, Most csak ezzel fogunk foglalkozni. Lényege, hogy a gép rezgéseit mérik, amiből eljárástól függően vagy az egész gép, vagy csak valamely gépelem állapotára lehet következtetni.
\end{abstract}

\section{Rezgésdiagnosztikai módszerek}

Mint már említettük a diagnosztikai módszerek közül ez a legelterjedtebb. Ezen mérési eljárásnak van a legtöbb fajtája, amelyeket mind összegyüjteni egy cikk keretében nem lehetséges. Ráadásul ezek különböző szempontok szerint is csoportosíthatók. Most a különböző eljárások közül csak azokat próbáljuk meg csoportba sorolni, amelyek fontosságuknál, gyakorlati alkalmazhatóságuknál fogva kitünnek a többi közül. A csoportosítást a következő szempontok alapján végezzük:

1, időbeliség szerint,

2, frekvenciatartomány szerint, 
3, mérendő változó szerint,

4, mért adatok feldolgozása szerint.

\section{A vizsgálat időbelisége szerinti cs oportosítás}

Ezen szempont alapján a diagnosztikai módszereket két nagy csoportba lehet sorolni:

- folyamatos figyelés

- időszakos figyelés

- Folyamatos figyelés: lényege, hogy mind az érzékelők, mind pedig az elemző műszerek állandó telepítésűek, müködésük folyamatos. Az elemek magas ára miatt csak olyan gépeknél berendezéseknél célszerü alkalmazni, amelyek a termelési láncban kulcsfontosságú szerepet töltenek be, így esetleges leállásuk nagy nyereségkiesést eredményezne.

Feladata egyrészről abban áll, hogy a mért jeleket feldolgozza, a kezelők számára valamilyen formában kijelezze. Másrészröl feladata, hogy a kapott eredményeket kielemezze, és a szükséges beavatkozást a lehető legrövidebb időn belül elvégezze. A beavatkozás lehet a gép leállítása, de szabályzókör esetén valamilyen paraméter módosítása is. Általában csak rezgés és hőmérséklet diagnosztika esetén alkalmazzák.

- Időszakos figyelés: Kevésbé fontos, vagy csak időszakosan üzemelő gépek esetén alkalmazzák. Az előzőtől abban különbözik, hogy bár a jel feldolgozása ekkor is azonnal megtörténik, az elemzés és az esetleges beavatkozás már időben elválik a méréstől. Bármilyen diagnosztikai módszer esetén alkalmazható.

\section{Frekvenciatartomány szerinti csoportosítás}

Csoportosítási szempontjaink szerint ez az első olyan kategória, amelynek kapcsán az egyes csoportokhoz tartozóan már konkrét mérési eljárásokat is be tudunk mutatni. Frekvenciatartomány szerint a következő csoportokat különböztethetjük meg:

- alacsony frekvenciatartományt $(100 \mathrm{~Hz}-10 \mathrm{kHz})$,

- magas frekvenciatartományt $(10 \mathrm{kHz}-100 \mathrm{kHz})$,

- akusztikus emisszió tartományát (100kHz-1000kHz).

- Alacsony frekvenciatartomány az a tartomány amelyben a hibák által keltett rezgések normál érzékelőkkel kimutathatók. Ezen mérési tartomány legjellegzetesebb rezgésdiagnosztikai módszere a rezgéserősség vizsgálata. 
A vizsgálatot az MSZ 1367-78 alapján kell elvégezni, amely előírja a mérés frekvenciatartományát és a megengedhető rezgéserősségi fokozatot. Ált. a méréseket $10 \mathrm{~Hz}-1 \mathrm{kHz}$ között kell effektív értékeket mérni. A mért effektív rezgéssebességi értékek közül a legnagyobbat kell mértékadónak tekinteni és ennek alapján a gépet egy ún. rezgéserősségi fokozatba kell sorolni

A rezgésmérő készülékek közös jellemzői, hogy nem képesek analizálni a rezgésjeleket, hanem csak effektív (esetleg csúcstól-csúcsig) értéket tudnak mérni.

A módszer állapotjelzésre alkalmas, mivel az egyes gépeken mért rezgéserősség időben nem állandó, hanem a gép üzemelési körülményeitöl, az életkorától, stb. függően folyamatosan változik. Ha egy adott gépen a méréseket megadott időközönként folyamatosan végezzük akkor az ún. "kád"-görbét kapjuk, amely alapján jól látszik, hogy a meghibásodás nem lehet váratlan, hiszen a rezgéserősség állandóan és folyamatosan nő a gép elhasználódásának mértékében.

Általánosságban elfogadott az a gyakorlat, hogy ha a mért rezgésszint az elfogadott alapszint két és félszeresére növekedik, akkor az már intő jelnek számít.

- Magas frekvencia tartomány a szerkezeti rezonanciára jellemző szakasz. Itt érzékelhetők a működésből származó lökésimpulzus jelek. A tartomány legjellegzetesebb rezgésdiagnosztikai módszere az ütésimpulzus módszer (SPM).

Az ezen módszerrel végzett mérések két egymással ütköző test közötti sebességkülönbség mértékére vonatkozóan adnak információt. Az ütközés révén ugyanis mindkét testben mechanikai lökéshullám keletkezik, amelynek csúcsértékét csak az ütközési sebesség határozza meg, s nem befolyásolja ezt az ütköző testek tömege és alakja. A tapasztalatok azt mutatják, hogy az üzemi állapot és a lökéshullámok nagysága között jól definiálható összefüggés áll fenn, amely két fogalommal irható le. Az egyik ezek közül a $\mathrm{dB}_{\mathrm{c}}$-vel jelölt ún. szőnyegérték, a másik a $\mathrm{dB}_{\mathrm{M}}-$ mel jelölt ún. maximális érték.

$A \mathrm{~dB}_{\mathrm{c}}$ szőnyegérték a felületi érdesség hatására alakul ki. Mivel a felület végtelen számú felületelemre bontható, így a sok kicsiny impulzus külön-külön már nem érzékelhető, csak az általuk meghatározott felület létezik. $\mathrm{A} \mathrm{dB}_{\mathrm{M}}$ maximális, vagy csúcsértéket a durva sérülések, vagy a nagy felületi egyenetlenségek, okozzák. Maga a $\mathrm{dB}_{\mathrm{M}}$ nem más, mint a mért legmagasabb lökésimpulzus érték.

Az üzemállapot megítéléséhez szükség van egy összehasonlitási alapra, ami nem más, mint egy, a mérendővel azonos típusú kifogástalan állapotú gépen mért ütésimpulzus. Ezt induló csillapítási értéknek nevezik, jele $\mathrm{dB}_{1}$. A gép állapotára egy olyan jellemző értéket állapíthatunk meg, amely az aktuális mért értékből az induló csillapítási érték levonásával keletkezik, és amelynek neve: normalizált lökéshullám érték.

A sérülés kialakulásának legbiztosabb jele sokkal inkább a folyamatosan növekvő lökéshullám értékek sorozata, mint az egyszeri leolvasásnál mért magas érték, így a méréseket célszerü rendszeres időközönként végezni. 
- Akusztikus emisszió tartomány az egymással érintkező felületek kiszakadásának kimutatására alkalmas. Akusztikus emissziónak a szilárd testek belsejében tárolt energia felszabadulásakor keletkező rugalmas anyaghullámokat nevezzük. Ezek az anyag belsejében gömbhullámok formájában terjednek, majd a test felületére érve felületi hullámokká alakulnak át. Ezeket a felületi hullámokat piezoelektromos-érzékelők segítségével felfogják, és elektromos jelekké alakítják át.

Az akusztikus emissziós hullámok leggyakoribb forrásai a különféle repedések és törések, így fő alkalmazási területük ezek kimutatása. Legjellemzőbb rezgésdiagnosztikai eljárása az SKF által kifejlesztett $S E E$ technológia, amelyet gördülőcsapágyak vizsgálatára alkalmaznak.

Az eljárásnak az a célja, hogy segítségével idejekorán észrevegyük, ha a csapágy kenése nem megfelelő, ill. sérült. Elvi alapja az a felismerés, miszerint nem csak akkor keletkeznek lökéshullámok, amikor a gürdülőtest áthalad egy csapágysérülés felett, hanem akkor is, amikor pillanatszerű fém-fémes érintkezés következik be a csapágyak müködése közben. A fém-fémes érintkezés a csapágyelemek közötti helyi túlhevüléssel jár együtt, s emiatt egy rövid időre e két érintkező pont összeheged. Mindez csak pillanatszerüen történik, hiszen ahogy a csapágy elfordul, az ideiglenes varrat elszakad. Ez a magyarázata annak, hogy ebben a magas frekvenciatartományban miért szolgáltat a csapágy fordulatszámától független eredményeket a SEE technológia.

\section{A mérendő változó szerinti csoportosítás}

Hogy a rezgés mely változóját mérhetjük, tulajdonképpen a rendelkezésünkre álló mérőfejek határozzák meg. Ezek a következők lehetnek:

- kitérés

- sebesség

- gyorsulás

- Rezgéskitérés értékeit mérik olyan gépek esetén, ahol a pontosság a meghatározó, tehát a kitérésre vonatkozó elöírt értékek betartását vizsgálják. Tipikusan ilyen gépek a különböző szerszámgépek.

- Rezgéssebesség mérése ad információt a gép állapotáról, a kialakult hibákról. Vagyis, ha a gépnek vagy valamely elemének az állapotára vagyunk kíváncsiak, akkor a rezgéssebesség értékeket vizsgáljuk. A vizsgálat itt is lehet egy elöírt határértékkel történő összehasonlítás, de általában spektrum analízist jelent.

- Rezgésgyorsulás mérése azon gépeknél kerül előtérbe, amelyek közvetlen kapcsolatban állnak emberekkel, mivel a szervezet számára az elszenvedett gyorsulás a meghatározó. Itt ismét az elöírt értékekkel történő összehasonlítás kerül előtérbe.

Mivel a kitérés, sebessége és gyorsulás közül bármelyiket a többiből integrálás vagy deriválás útján megkaphatjuk, így egy mérőfejjel akár mindhárom jellemző mérését is el tudjuk végezni. Ügyelnünk kell 
azonban arra, hogy míg integrálásnál a Fourier közelítés konvergenciája nő, addig deriválás esetén csökken.

\section{A mért adatok feldolgozása szerinti csoportosítás}

Ez arra vonatkozik, hogy ha az előző pontban tárgyalt rezgésjellemzők közül valamelyiket megmértük és rögzítettük, akkor hogyan dolgozhatjuk fel a további elemzés céljából. Ezen szempontból a következő csoportok között tehetünk különbséget:

- nem analizálják

- korreláció analízis

- spektrum analízis

- kepstrum analízis

- nem analizálják: ez azt jelenti, hogy a rezgésmérés során rögzített adatokból közvetlenül állapítják meg a diagnózist. Ilyen eljárás pl. a már korábban bemutatott rezgéserősség mérés.

- korreláció analizis: azt mutatja meg, hogy van-e valamilyen kapcsolat a jel egy adott időpontbeli és egy későbbi időpontban felvett értéke között. Ezzel a sztochasztikus jelben lévő periodicitás kimutatható. Két fajtája használt, a kereszt- és az autókorreláció. Az autókorreláció egy x sztochasztikus időjelnek a ta és tb időpontban felvett értékeinek a kapcsolatát szolgáltatja, az értékek szorzatának várható értéke formájában. A keresztkorreláció azt adja meg, hogy egy x sztochasztikus időjelnek a ta időpillanatban felvett értékeit egy másik y sztochasztikus időjelnek a tb időpontban felvett értékeivel összeszorozva mekkora a szorzat várható értéke.

- spektrum analizis: A determinisztikus jelek közül a periodikus jelek a frekvencia tartományban amplitúdó- és fázisspektrummal, az aperiodikus jelek pedig amplitúdó- és fázissürüség spektrummal jellemezhetők. A spektrum elöállítása a Fourier-transzformációval történik, amely az időjelet frekvenciaösszetevőkre bontja. Célja, hogy a különböző frekvenciákhoz tartozó amplitúdók ill. amplitudósürüségek nagysága alapján a hibás elem behatárolható legyen.

- kepstrum analízis: ez egy sor olyan függvényeket alkalmazó technikai eljárás, amely függvények úgy tekinthetök, mint egy logaritmikus spektrum spektruma. felhasználási területe hasonló a korrelációs függvényekéhez, annak felváltására találták ki. Ténylegesen a kepstrum manapság leginkább használatos definíciója az, hogy a logaritmikus teljesítményspektrum fordított Fourier transzformációja, amely lényegében csak a spektrum logaritmikus átalakításában különbözik az autókorrelációtól.

Rácz József, doktorjelölt

Miskolci egyetem, Gépelemek Tanszéke, Miskolc-Egyetemváros

H-3515, HUNGARY, Tel/Fax: +36-46-327-643 